\title{
Performance evaluation of an side-stream anaerobic membrane bioreactor: Synthetic and alcoholic beverage industry wastewater
}

\author{
Yan akımlı anaerobik membran biyoreaktör veriminin araştırılması: \\ Sentetik atıksu ve alkollü içki sanayi atıksuyu
}

\author{
Nurdan BÜYÜKKAMACI ${ }^{*}$, Yunus AKSOY2 \\ 1Department of Environmental Engineering, Engineering Faculty, Dokuz Eylul University, Izmir, Turkey. \\ nurdan.buyukkamaci@deu.edu.tr \\ 2Department of Environmental Engineering, Engineering Faculty, Firat University, Elazıg, Turkey. \\ yaksoy@firat.edu.tr
}

Received/Geliş Tarihi: 16.10.2014, Accepted/Kabul Tarihi: 02.02.2015

* Corresponding author/Yazıșlan Yazar

doi: $10.5505 /$ pajes.2015.48343

Research Article/Araștırma Makalesi

\section{Abstract}

The treatment performance of a laboratory-scale anaerobic membrane bioreactor (AnMBR) using high strength wastewater was evaluated. The AnMBR model system consisted of an up-flow anaerobic sludge blanket reactor (UASB) and an ultrafiltration (UF) membrane. Its performance was first examined using molasses based synthetic wastewater at different hydraulic retention times (1-3 days) and organic loading rates $\left(5-15 \mathrm{~kg} \mathrm{COD} / \mathrm{m}^{3}\right.$.day). As a result of the experimental studies, maximum treatment efficiency with respect to COD reduction (95\%) was achieved at $7.5 \mathrm{~kg} C O D / \mathrm{m}^{3}$.day OLR (COD influent $=15.000 \mathrm{mg} / \mathrm{L}, H R T=2$ days) applications. When OLR was increased to $15 \mathrm{~kg} \mathrm{COD} / \mathrm{m}^{3}$.day, system performance decreased sharply. Similarly, methane gas production decreased by increasing OLR. After then, feed was changed to real wastewater, which was alcoholic beverage industry effluent. At this study, maximum COD removal efficiency of the system and maximum methane gas production was $88 \%$ and $74 \%$, respectively.

Keywords: Anaerobic, Membrane, Wastewater, Alcoholic beverage industry
Öz

Yan akımlı anaerobik membran biyoreaktörlerin verimi yüksek kirliliğe sahip atıksular için laboratuvar ölçekli bir sistem kullanılarak irdelenmistir. Sistem, yukarı akışl çamur yataklı anaerobik (UASB) reaktör ve ultrafiltrasyon (UF) membran modülünden olușturulmuştur Sistemin verimi öncelikle seyreltilmiș melastan hazırlanan sentetik atıksu ile farklı hidrolik alıkonma süreleri (1-3 gün) ve organik yükleme oranlarında $\left(5-15 \mathrm{~kg} \mathrm{KOI} / \mathrm{m}^{3}\right.$.day) incelenmiștir. Yapılan deneysel callsmalar neticesinde, maksimum KOI giderme verimi (\%95) $7.5 \mathrm{~kg}$ $\mathrm{KOI} / \mathrm{m}^{3}$.gün organik yükleme değerinde $\left(\mathrm{KOI}_{\text {giris }}=15.000 \mathrm{mg} / \mathrm{L}, \mathrm{HRT}=2\right.$

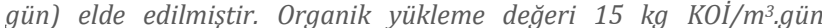
değerine çıkartıldığında sistem performansı aniden düssmüştür. Daha sonra, besleme suyu bir alkollü içki sanayi atıksuyu ile değiștirilerek gerçek atıksu ile çalışmalar yürütülmüştür. Bu çalışmada, maksimum toplam sistem verimi ve metan gazı oluşumu sirasiyla \%88 ve \%74 olarak belirlenmiștir.

Anahtar kelimeler: Anaerobik, Membran, Atıksu, Alkollü içki sanayi

\section{Introduction}

Due to the capacity of operation with high organic loads (OLR), the anaerobic membrane bioreactors (AnMBR) are considered to be a superior alternative for the treatment of high strength organic wastewaters [1],[2]. An AnMBR can be simply defined as a biological treatment process operated without oxygen and using a membrane to provide solid-liquid separation [2].

The applicable organic load changes depending on the wastewater properties, operational conditions, and the design of the reactors. Lin et al. (2013) reported that most studies regarding AnMBR applied lower than $10 \mathrm{~kg} \mathrm{COD} / \mathrm{m}^{3} . \mathrm{d}$ [2]. He et al. (2005) reported that COD removal efficiencies higher than $90 \%$ and $80 \%$ were obtained at organic loading rates of 2.0 $\mathrm{kg} / \mathrm{m}^{3} . \mathrm{d}$ and $2.0-4.5 \mathrm{~kg} / \mathrm{m}^{3} . \mathrm{d}$, respectively for high strength food wastewater [3]. In another study, OLR of $20 \mathrm{~kg} / \mathrm{m}^{3} . \mathrm{d}$, $8 \mathrm{~kg} / \mathrm{m}^{3} . \mathrm{d}$ and $6-8 \mathrm{~kg} / \mathrm{m}^{3} . \mathrm{d}$ was applied for synthetic wastewater, for the vegetable processing industry (sauerkraut brine) wastewater and for the wastewater from an animal slaughterhouse, respectively. COD removal efficiencies above $90 \%$ were obtained in all applications [4]. Bohdziewicz et al. (2008) found the highest efficiency in terms of COD removal $90 \%$ at hydraulic retention time (HRT) of 2 days and OLR of 2.5 $\mathrm{kg} \mathrm{COD} / \mathrm{m}^{3} . \mathrm{d}$ for landfill leachate treatment by an anaerobic submerged membrane bioreactor [5]. A slaughterhouse that used AnMBR to treat wastewater achieved about 94\% average COD removal efficiency at OLRs between 4.37 and $13.27 \mathrm{~kg}$ $\mathrm{COD} / \mathrm{m}^{3} \cdot \mathrm{d}[6]$.

Although there are several studies about AnMBR in the literature, as reported by Dereli et al., there is still a large knowledge gap for the design and operation of full-scale AnMBRs [7]. The purpose of the present study is to evaluate the performance of an anaerobic side-stream membrane bioreactor under different operational conditions for high strength wastewater (i.e. synthetic wastewater and alcoholic beverage industry effluent) for optimum design conditions and for operating full scale AnMBR systems.

\section{Materials and methods}

\subsection{Laboratory scale AnMBR system}

Experimental studies were carried out using a side-stream (external) AnMBR consisting of an anaerobic reactor and an ultrafiltration (UF) unit (Figure 1). The side-stream configuration was selected due to their some advantages such as easier membrane replacement and fouling control.

The feeding tank and anaerobic reactor are made of stainless steel. The anaerobic reactor was designed as an up-flow anaerobic sludge blanket (UASB) reactor. There is no mixing device and gas/liquid/solid separation system in the anaerobic 
reactor. It was operated under mesophilic $\left(36 \pm 1^{\circ} \mathrm{C}\right)$ conditions and the temperature was kept constant by circulating hot water through the reactor jacket. With a total volume of 10 liters, the anaerobic reactor was equipped with inlet and outlet valves, sampling valves, and gas and sludge outlet valves. Wastewater was introduced to the anaerobic reactor at the bottom and effluent was withdrawn from the top of the reactor and pumped to the UF unit.

A hollow fiber polysulfone membrane in Pall's Microza module (SLP-1053) was used as the membrane module following-anaerobic reactor. The molecular weight cut-off and surface area of the membrane was $10 \mathrm{kDa}$ and $0.1 \mathrm{~m}^{2}$, respectively. A peristaltic pump was used to pump the wastewater to the membrane system. Inlet and outlet pressure was measured using pressure measurement devices attached to the module. The inlet pressure was kept constant at $1.5 \pm 0.2$ bars during the experiments. The maximum wash and backwash pressures for the UF membrane were 1.7 and 2.5 bar, respectively.

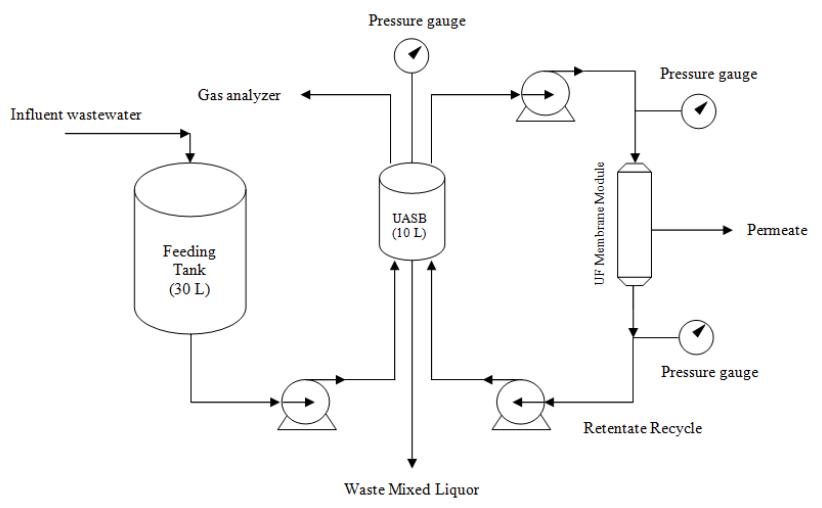

Figure 1: The flow scheme of the model system.

\subsection{Wastewater characteristics}

After the start-up phase, high strength synthetic wastewater consisting of the diluted molasses was first used. The composition of synthetic wastewater is given in Table 1 . The COD concentration range of some high strength industrial wastewaters including yeast factory effluent, sugar industry effluent, and fermentation industry effluent changes between 8.000-30.000 mg/L [8]-[11]. Therefore, COD concentrations range of the synthetic wastewater was selected considering the above COD concentration range of high strength industrial wastewaters.

Following the study with synthetic wastewater, raw alcoholic beverage industry effluent was fed to the model reactor. The COD concentration of the wastewater used in this study was about $5600 \pm 800 \mathrm{mg} / \mathrm{L}$ and $\mathrm{pH}$ of the wastewater ranged between 6.1-10.8.

\subsection{Analytical procedure}

During the experimental study, analyses of $\mathrm{pH}$, total chemical oxygen demand (COD), alkalinity, volatile fatty acids, total solids (TS), total volatile solids (TVS), total suspended solids (TSS), and volatile suspended solids (VSS) were carried out according to Standard Methods [12]. The pH was measured using the WTW model 340i multi analyzer. The composition of the biogas $\left(\mathrm{CH}_{4}\right.$ and $\left.\mathrm{CO}_{2}\right)$ was measured using a Dräger $\mathrm{X} \mathrm{AM}$ 7000 multi gas measurement device. Total biogas and methane production volume were also determined by the liquid displacement methods.

Table 1: The composition of the synthetic wastewater

\begin{tabular}{ll}
\hline \multicolumn{1}{c}{ Parameter } & \multicolumn{1}{c}{ Range } \\
\hline COD, mg/L & $15.000-20.000$ \\
TS, mg/L & $18.800 \pm 3.300$ \\
TVS, mg/L & $15.700 \pm 2950$ \\
TSS, mg/L & $250 \pm 125$ \\
TVS, mg/L & $85 \pm 70$ \\
Total nitrogen, mg/L & $26 \pm 1$ \\
Phosphate, mg/L & $1.5 \pm 0.9$ \\
pH & $7 \pm 2$ \\
\hline
\end{tabular}

\section{$2.4 \quad$ Start-up phase}

The anaerobic reactor was inoculated by adding sludge produced in the anaerobic reactors of PAKMAYA Baker's Yeast Company (Izmir, Turkey) Wastewater Treatment Plant. The model reactor was operated at 5 days HRT and at an OLR of 0.4 $\mathrm{kg} / \mathrm{m}^{3} . \mathrm{d}$ with an influent COD concentration of $2000 \mathrm{mg} / \mathrm{L}$ at the start-up phase. The system has reach to steady-state conditions after 30 days continuous operation.

\subsection{Operational conditions}

After the reactor start-up stage, the influence of HRT and OLR were investigated. In this scope, four different operational conditions given in Table 2 were applied during the studies with synthetic wastewater. System performance was evaluated at three hydraulic retention times $(3,2$, and 1 days) and two influent COD concentrations (15.000-20.000 mg/L). There was about two weeks between tested phases for reaching steadystate conditions and after then the model reactor was operated about one month at each phase.

Table 2: Applied operational conditions.

\begin{tabular}{|c|c|c|c|c|}
\hline & & $\begin{array}{c}\text { Influent COD } \\
\text { Concentration, } \\
\mathrm{mg} / \mathrm{L}\end{array}$ & $\begin{array}{c}\text { Hydraulic } \\
\text { Retention Time } \\
\text { (HRT), day }\end{array}$ & $\begin{array}{c}\text { Organic } \\
\text { Loading Rate } \\
\text { (OLR), kg } \\
\mathrm{COD} / \mathrm{m}^{3 *} \text { day }\end{array}$ \\
\hline \multirow{4}{*}{ 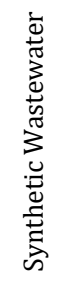 } & Phase I & 15000 & 3 & 5 \\
\hline & Phase II & 15000 & 2 & 7.5 \\
\hline & Phase III & 15000 & 1 & 15 \\
\hline & Phase IV & 20000 & 2 & 10 \\
\hline \multicolumn{2}{|c|}{$\begin{array}{l}\text { Beverage } \\
\text { Wastewater }\end{array}$} & $5600 \pm 800$ & 2 & $2.4-3.2$ \\
\hline
\end{tabular}

Following the studies with synthetic wastewater, alcoholic beverage industry effluent was fed to the model reactor for about a month. The operational conditions were adjusted considering the optimum conditions which had been determined in previous study carried out with synthetic wastewater. Since the maximum treatment efficiency was achieved at 2 days of HRT, the hydraulic retention time was kept constant at 2 days ( $Q=5 \mathrm{~L} /$ day) during the synthetic 
wastewater experiments. The organic loading rate was between $2.4-3.2 \mathrm{~kg}$ COD m${ }^{3}$ per day depending on the influent COD concentrations (Table 2).

\section{Results and discussion}

\subsection{Synthetic wastewater}

The $\mathrm{pH}$, alkalinity and VFA/Alkalinity ratio changes in the anaerobic reactor effluent were monitored regularly. There was no significant $\mathrm{pH}$ fluctuation and the average $\mathrm{pH}$ of the effluent was 6.9. The alkalinity and VFA in the anaerobic reactor effluent was measured between 2800-4400 $\mathrm{mg} \mathrm{CaCO}_{3} / \mathrm{L}$ and 200-2500 mg/L, respectively. A decrease in the alkalinity and an increase in the VFA with increasing OLR were observed. The VFA and alkalinity, separately, are not good indicators for evaluating the process stability of the anaerobic reactor, since total alkalinity reflect both levels of VFA and bicarbonate, and unstable conditions increased VFA, and reduced the bicarbonate, resulting in constant total alkalinity [13]. Thus, the ratio of VFA to alkalinity is the best option to monitor process stability in anaerobic systems. As reported by Zhao and Viraraghavan (2004) if VFA/Alkalinity ratio exceeds 0.8, the inhibition of methanogens occurs and the process failure is apparent [14]. In this study, VFA/Alkalinity ratio varied between 0.1 and 1.02. At higher OLR applications (Phase III and IV), ratios above 0.8 were measured. In order to protect the methanogenic and acetogenic populations from VFAs accumulation, a certain amount of alkalinity was added regularly.

Maximum COD removal efficiencies for the anaerobic reactor, the UF membrane unit, and the overall system (AnMBR) are shown in Figure 2. In the anaerobic reactor, maximum COD removals of $55 \%, 80 \%, 63 \%$ and $61 \%$ were obtained for OLRs of $5 \mathrm{~kg} \mathrm{COD} / \mathrm{m}^{3} . \mathrm{d}$ (Phase I), $7.5 \mathrm{~kg} \mathrm{COD} / \mathrm{m}^{3} . \mathrm{d}$ (Phase II), $15 \mathrm{~kg}$ $\mathrm{COD} / \mathrm{m}^{3} . \mathrm{d}$ (Phase III), and $10 \mathrm{~kg} \mathrm{COD} / \mathrm{m}^{3} . \mathrm{d}$ (Phase IV), respectively. Although influent COD concentrations of Phase I-II and III are the same, decreasing HRT was applied for these experiments. As seen from the Figure 2, organic material removal efficiencies of the anaerobic reactor decrease with decreasing HRT and increasing OLR. Skouteris et al. (2012) indicated that, when the organic loading rate increases, the risk of a deteriorated performance due to volatile fatty acids (VFAs) accumulation may occur, and lower COD removal efficiencies are achieved due to the inhibition of microbial activity [15]. As indicated above, increase in VFA with increasing OLR was also observed in this study.

The COD removal efficiencies of the UF membrane decreased from $75 \%$ to $46 \%$ as operation continued. In MBR systems, COD is removed by both physical and biological mechanisms. Amri (2010) indicated that although the biological COD removal increases in time, the COD removal by the membrane decreases in time because of the age of the membrane and membrane fouling [16]. However, some researchers pointed out that the fouling layer at the membrane surface provides extra filtration activity and removal efficiency increases [17]. The other reason for the decrease in membrane efficiency may be the increase in the organic matter concentration of influent wastewater. Since influent COD concentrations increased throughout the experimental study, organic material content of the anaerobic reactor effluent also increased over time.

In terms of overall system (AnMBR) performance, maximum COD removal efficiencies of $85 \%, 95 \%, 88 \%$, and $79 \%$ were obtained at $5 \mathrm{~kg} \quad \mathrm{COD} / \mathrm{m}^{3} \cdot \mathrm{d} \quad$ (CODinfluent $=15.000 \mathrm{mg} / \mathrm{L}$,
HRT=3 day), $7.5 \mathrm{~kg} \mathrm{COD} / \mathrm{m}^{3} . \mathrm{d}\left(\mathrm{COD}_{\text {influent }}=15.000 \mathrm{mg} / \mathrm{L}, \mathrm{HRT}=2\right.$ day), $15 \mathrm{~kg} \mathrm{COD} / \mathrm{m}^{3} \cdot \mathrm{d}$ (CODinfluent $=15.000 \mathrm{mg} / \mathrm{L}, \mathrm{HRT}=1$ day) and $10 \mathrm{~kg} \mathrm{COD} / \mathrm{m}^{3} \cdot \mathrm{d}\left(\mathrm{COD}_{\text {influent }}=20.000 \mathrm{mg} / \mathrm{L}, \mathrm{HRT}=2\right.$ day) of OLRs, respectively. The lowest efficiency of $79 \%$ was obtained at the highest influent COD concentration feeding (Phase IV). In a study carried out with synthetic wastewater consisted of molasses $78-81 \%$ COD removal were obtained at $14.9-5.6 \mathrm{~kg}$ $\mathrm{COD} / \mathrm{m}^{3} . \mathrm{d}$ of OLR and $16-32 \mathrm{~h}$ of HRT [18].

The decrease in HRT negatively influenced the COD removal in the AnMBR. However, Stuckey (2012) reported that some researchers operated such systems at HRT as low as $4 \mathrm{~h}$ and $97 \%$ COD removal could be achieved at temperatures down to $13{ }^{\circ} \mathrm{C}[19]$.

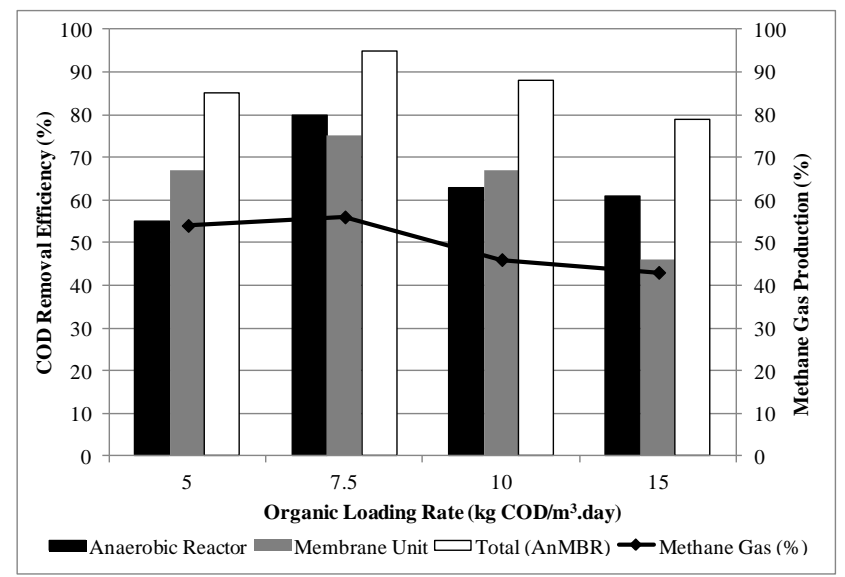

Figure 2: Performance of the system vs. organic loading rates for synthetic wastewater.

Average methane gas percentage of the total produced biogas during Phase I (5 kg COD $\left./ \mathrm{m}^{3} . \mathrm{d}\right)$, Phase II (7.5 kg COD $/ \mathrm{m}^{3} . \mathrm{d}$ ), Phase III (15 kg COD $\left./ \mathrm{m}^{3} . \mathrm{d}\right)$, and Phase IV (10 kg COD $\left./ \mathrm{m}^{3} . \mathrm{d}\right)$ were observed as $54 \%, 56 \%, 46 \%$, and $43 \%$, respectively (Figure 2). It was observed that methane content of the total produced biogas decreased with an increase in the OLR and with a decrease in the HRT. Since methane production is the key parameter for an efficient anaerobic biodegradation, lower methane contents represented that high organic loading and low hydraulic retention time negatively affected the performance of the AnMBR system.

During the experimental studies, average total and volatile solids concentrations in the anaerobic reactor effluent were $7.000 \mathrm{mg} / \mathrm{L}$ and $2.660 \mathrm{mg} / \mathrm{L}$, respectively. UF did not indicate any effective TS and TVS removals with respective maximum efficiencies of $25 \%$ TS and $38 \%$ and with respective average efficiencies of $15 \%$ and $31 \%$. The UF membrane system can produce high quality water, free of suspended solids, colloidal material, and bacteria [20]. As expected, high total suspended solids $(97 \%$ average $)$ and volatile suspended solids ( $93 \%$ average) removals were obtained with the UF membrane system in this study. Figure 3 shows a noticeable elimination of suspended solids by the change of the permeate turbidity.

\subsection{Alcoholic beverage wastewater}

Although the influent $\mathrm{pH}$ changed in a wide range (i.e. 6.1-10.8), $\mathrm{pH}$ values in the effluents of the anaerobic reactor and membrane unit, which were in the range of 7.1-7.6 and 7.3-7.8, respectively, were almost constant. The average alkalinity and volatile fatty acids in the anaerobic reactor effluent was $1400 \mathrm{mg} / \mathrm{L}$ and $210 \mathrm{mg} / \mathrm{L}$, respectively. Thus, 
VFA/Alkalinity ratio was about 0.15 during the operational period.

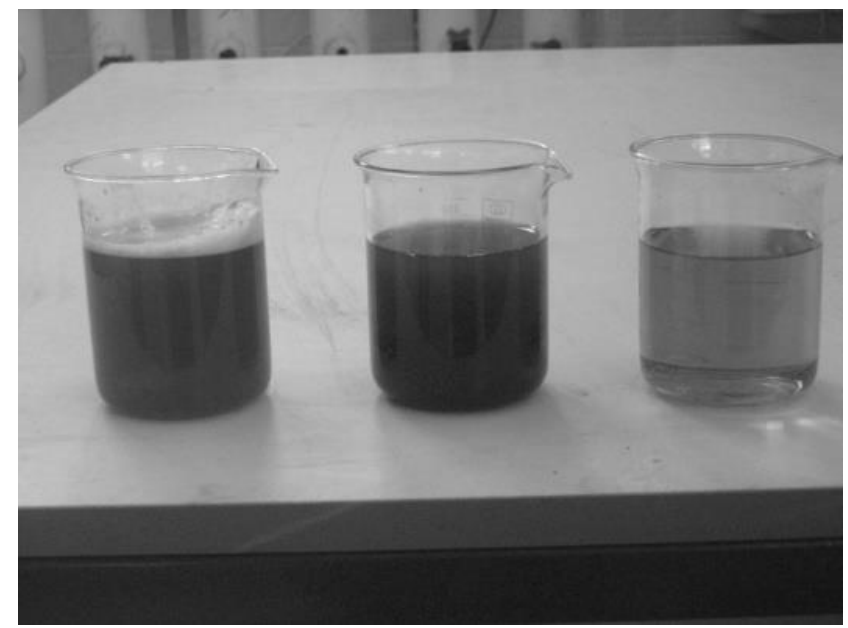

Figure 3: Feeding wastewater (left), anaerobic reactor effluent (middle), permeate (right).

Total COD removal performance of the model reactor for alcoholic beverage industry effluent was illustrated in Figure 4. The COD concentrations of raw influent were $5600 \pm 800 \mathrm{mg} / \mathrm{L}$, and that of AnMBR effluent remained 800 $\mathrm{mg} / \mathrm{L}$ at steady-state conditions. COD removal efficiencies of the model reactor changed from 69 to $88 \%$, while the average was $82 \%$. Torres et al. (2011) operated a lab-scale AnMBR operated with external membrane modules containing inside/out tubular membranes and higher than 97\% COD removal was obtained in an OLR range up to $12 \mathrm{~kg} \mathrm{COD} / \mathrm{m}^{3} . \mathrm{d}$ [21].

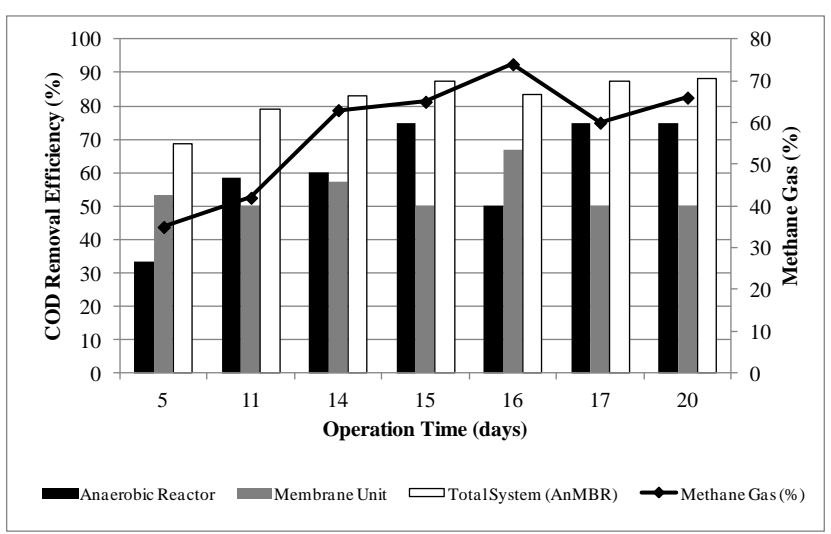

Figure 4: Performance of the system for alcoholic beverage industry effluent.

A higher methane gas percentage $(74 \%)$ was obtained in studies with beverage wastewater, compared to that of obtained with synthetic wastewater treatment. Wastewater from beverage production facilities contains easily biodegradable organic compounds $\left(\mathrm{BOD}_{5} / \mathrm{COD}=\sim 0.5\right)$ and treatment of this type of wastewater usually comprises of physical pre-treatment for removal of suspended matter followed by biological treatment, either aerobic or anaerobic [21]. Matošić et al. (2009) compared the performances of an aerobic MBR and a conventional activated sludge process treating beverage industry effluent [22]. Results of the study indicated that, MBR successfully removed the pollutants in terms of COD, BOD, and TOC from the wastewater with an efficiency of over $90 \%$. However, it must be kept in mind that

aerobic systems consume huge amount of energy while the anaerobic processes produce methane, which is a valuable energy source.

\section{Conclusions}

Treatment studies of both synthetic and real high strength wastewater were carried out using a laboratory-scale sidestream anaerobic membrane bioreactor (AnMBR), consisting of an up-flow anaerobic sludge blanket (UASB) reactor and an ultrafiltration (UF) membrane. Results of the study with synthetic wastewater indicated that, maximum COD efficiency $(95 \%)$ was achieved at an OLR of $7.5 \mathrm{~kg} \mathrm{COD} / \mathrm{m}^{3}$.day. When OLR increased two-fold, system performance decreased sharply. Similarly, methane gas production decreased by increasing OLR. On the other hand, results of the study with rawalcoholic beverage industry effluent, maximum $88 \%$ COD removal was obtained. As a conclusion, it was found that, anaerobic membrane bioreactors can be applied to treat high strength organic wastewaters. AnMBR is a good alternative for treating these types of wastewaters providing high quality effluent.

\section{Acknowledgement}

The authors gratefully acknowledge the Scientific and Technical Research Council of Turkey (TUBITAK), Project No: 110Y020, for financial support.

\section{References}

[1] Visvanathan C, Abeynayaka A. "Developments and future potentials of anaerobic membrane bioreactors (AnMBRs)". Membrane Water Treatment, 3(1), 1-23, 2011.

[2] Lin H, Peng W, Zhang M, Chen J, Hong H, Zhang Y. "A review on anaerobic membrane bioreactors: applications, membrane fouling and future perspectives". Desalination, 314, 169-188, 2013.

[3] He Y, Xu P, Li C, Zhang B. "High-Concentration food wastewater treatment by an anaerobic membrane bioreactor". Water Research, 39(17), 4110-4118, 2005.

[4] Fuchs W, Binder H, Mavrias G, Braun R. "Anaerobic treatment of wastewater with high organic content using a stirred tank reactor coupled with a membrane filtration unit". Water Research, 37(4), 902-908, 2003.

[5] Bohdziewicz J, Neczaj E, Kwarciak A. "Landfill leachate treatment by means of anaerobic membrane bioreactor". Desalination, 221(1-3), 559-565, 2008.

[6] Saddoud A, Sayadi S. "Application of acidogenic fixed-bed reactor prior to anaerobic membrane bioreactor for sustainable slaughterhouse wastewater treatment". Journal of Hazardous Materials, 149(3), 700-706, 2007.

[7] Dereli RK, Ersahin ME, Ozgun H, Ozturk I, Jeison D, Zee F, Lier JB. "Potentials of anaerobic membrane bioreactors to overcome treatment limitations induced by industrial wastewaters". Bioresource Technology, 122, 160-170, 2012.

[8] Deveci N, Ciftci G. "A Mathematical model for the anaerobic treatment of baker's yeast effluents". Waste Management, 21(1), 99-103, 2001.

[9] Özkan E, Uyar B, Özgür E, Yücel M, Eroğlu I, Gündüz U. "Photofermentative hydrogen production using dark fermentation effluent of sugar beet thick juice in outdoor conditions". International Journal of Hydrogen Energy, 37(2), 2044-2049, 2012. 
[10] Petruccioli M, Duarte JC, Federici F. "High-Rate aerobic treatment of winery wastewater using bioreactors with free and immobilized activated sludge". Journal of Bioscience and Bioengineering, 90(4), 381-386, 2000.

[11] Parawira W, Kudita I, Nyandoroh MG, Zvauya R. "A study of industrial anaerobic treatment of opaque beer brewery wastewater in a tropical climate using a full-scale UASB reactor seeded with activated sludge". Process Biochemistry, 40(2), 593-599, 2005.

[12] American Public Health Association (APHA), American Water Works Association (AWWA) \& The Water Environment Federation (WEF). "Standard Methods for the Examination of Water and Wastewater" (21st ed.), American Public Health Association, Washington, District of Columbia, USA, 2005.

[13] Wijetunga S, Wenquan R, Li X, Chen J. "Decolourization of textile wastewater containing acid dyes in UASB reactor system under mixed anaerobic granular sludge". Electronic Journal of Environmental, Agricultural and Food Chemistry, 5(1), 1224-1234, 2006.

[14] Zhao HW, Viraraghavan T. "Analysis of the performance of an anaerobic digestion system at the Regina wastewater treatment plant". Bioresource Technology, 95(3), 301-307, 2004.

[15] Skouteris G, Hermosilla D, López P, Negro C, Blanco Á. "Anaerobic membrane bioreactors for wastewater treatment: A review". Chemical Engineering Journal, 198199, 138-148, 2012.
[16] Amri AAA. The Performance of Membrane Bioreactor in Treating High Temperature Municipal Wastewater. Ph.D. (Dissertation). Universiti Teknologi Malaysia, Skudai, Malaysia, 2010.

[17] Park JS, Lee CH. "Removal of soluble COD by a biofilm formed on a membrane in a jet loop type membrane bioreactor". Water Research, 39(19), 4609-4622, 2005.

[18] Lin H, Peng W, Zhang M, Chen J, Hong H, Zhang Y. "A review on anaerobic membrane bioreactors: applications, membrane fouling and future perspectives". Desalination, 314, 169-188, 2013.

[19] Stuckey DC. "Recent developments in anaerobic membrane reactors". Bioresource Technology, 122, 137-148, 2012.

[20] Taylor JS, Wiesner M. Membranes Editor: Letterman RD. Water Quality and Treatment, $5^{\text {th }}$ ed, 11.1-11.71, New York, USA, McGraw Hill, 1999.

[21] Torres A, Hemmelmann A, Vergara C, Jeison D. "Application of two-phase slug-flow regime to control flux reduction on anaerobic membrane bioreactors treating wastewaters with high suspended solids concentration". Separation and Purification Technology, 79(1), 20-25, 2011.

[22] Matošić M, Prstec I, Korajlija JH, Mijatović I. “Treatment of beverage production wastewater by membrane bioreactor". Desalination, 246(1-3), 285-293, 2009. 